\title{
Status Mineral Darah (Ca, P, Mg, Zn, Cu) Kambing Kacang yang diberi Pakan Pelengkap Multinutrien Blok
}

\author{
Muhamad Dinar Arrizqi, Baginda Iskandar Moeda Tampoebolon, \\ Surahmanto, Retno Iswarin Pujaningsih \\ Departemen Peternakan, Fakultas Peternakan dan Pertanian, Universitas \\ Diponegoro, Kompl. drh. R. Soejono Koesoemowardojo, Tembalang \\ Semarang Kode Pos 50275 \\ E-mail: muhdinar99@gmail.com
}

\begin{abstract}
ABSTRAK
Penelitian untuk mengkaji status mineral darah (ca, p, mg, zn, cu) kambing kacang yang diberi pakan pelengkap multinutrien blok. Materi yang digunakan dalam penelitian ini antara lain obat cacing, multinutrien blok (MNB), pakan, alkohol dan 12 ekor kambing kacang jantan umur 7 bulan sehat secara klinis dengan 4 perlakuan level MNB yang berbeda. Kambing dibagi kedalam 3 kelompok bobot badan yaitu Kelompok I : 17,5 - $20 \mathrm{~kg}$, Kelompok II : 15 - 16,5 kg, Kelompok III : 13,5 - $15 \mathrm{~kg}$ setiap kelompok berisi 4 ekor kambing. Setiap kelompok kambing mendapat 4 perlakuan berbeda berupa level pemberian MNB. Alat yang digunakan terdiri dari 12 buah kandang individu, 12 palung, 12 ember, 12 buah spet $10 \mathrm{ml}$ dan jarum suntik, label, 12 buah tabung vacuulab dengan EDTA, cooling box, alkohol dan alat tulis untuk mencatat serta memberi label pada sampel darah. Kambing dibagi kedalam 3 kelompok bobot badan setiap kelompok berisi 4 ekor kambing yang melipti T0 : Hijauan + Konsentrat + Tanpa Pemberian MNB, T1 : Hijauan + Konsentrat + MNB sebanyak $5 \mathrm{~g}$, T2 : Hijauan + Konsentrat + MNB sebanyak $10 \mathrm{gr}$ dan T3 : Hijauan + Konsentrat + MNB sebanyak $15 \mathrm{~g}$. Parameter yang diamati yaitu kadar $\mathrm{Ca}, \mathrm{P}, \mathrm{Mg}, \mathrm{Zn}$ dan $\mathrm{Cu}$ di dalam plasma darah kambing. Data analisis menggunakan analisis ragam dan dilanjutkan dengan uji lanjut wilayah ganda Duncan. Hasil penelitian menunjukkan bahwa pemberian $\mathrm{MNB}(0,5,1015 \mathrm{~g})$ tidak berpengaruh terhadap status mineral $(\mathrm{Ca}, \mathrm{P}, \mathrm{Mg}, \mathrm{Zn}, \mathrm{Cu})$ dalam plasma darah kambing kacang. Simpulan dari penelitian ini bahwa pemberian MNB $(0,5,10,15 \mathrm{~g})$ memberikan efek yang sama terhadap status mineral ( $\mathrm{Ca}, \mathrm{P}, \mathrm{Mg}, \mathrm{Zn}, \mathrm{Cu})$ dalam plasma darah kambing kacang.
\end{abstract}

Kata Kunci : Multinutrien blok, kambing kacang, status mineral, plasma darah.

\begin{abstract}
Research to assess the status of blood minerals (ca, p, $\mathrm{mg}, \mathrm{zn}, \mathrm{cu}$ ) of Kacang goats fed with multinutrient block supplement. The materials used in this study include worming, multinutrient block (MNB), feed, alcohol and 12 male goats aged 7 months clinically healthy with 4 different MNB level treatments. Goats are divided into 3 groups of body weights, namely Group I: 17.5 - $20 \mathrm{~kg}$, Group II: 15 - $16.5 \mathrm{~kg}$, Group III: 13.5 - $15 \mathrm{~kg}$ each group contains 4 goats. Each group of goats received 4 different treatments in the form of the level of MNB administration. The equipment used consisted of 12 individual cages, 12 troughs, 12 buckets, $1210 \mathrm{ml}$ spets and syringes, labels, 12 vacuulab tubes with EDTA, cooling box, alcohol and stationery to record and label blood samples. Goats are divided into 3 weight groups each group containing 4 goats which includes T0: Forage + Concentrate + Without Giving MNB, T1: Forage + Concentrate + MNB of 5 g, T2: Forage + Concentrate + MNB of $10 \mathrm{gr}$ and T3: Forage + Concentrate + MNB of $15 \mathrm{~g}$. The parameters observed were changes levels of $\mathrm{Ca}, \mathrm{P}, \mathrm{Mg}$, Zn and $\mathrm{Cu}$ in goat blood plasma. Data analysis used analysis of variance and continued with Duncan's multiple region test. The results showed that the administration of $M N B(0,5,1015 \mathrm{~g})$ did not affect the mineral status $(\mathrm{Ca}, \mathrm{P}, \mathrm{Mg}, \mathrm{Zn}, \mathrm{Cu})$ in the blood plasma of Kacang goats. The conclusion of this study is that the administration of $M N B(0,5,10,15 \mathrm{~g})$ has the same effect on the mineral status ( $\mathrm{Ca}, \mathrm{P}, \mathrm{Mg}, \mathrm{Zn}, \mathrm{Cu})$ in the blood plasma of Kacang goats.
\end{abstract}

Keywords: Multinutrient block, Kacang goats, mineral status, blood plasma. 


\section{PENDAHULUAN}

Kambing merupakan salah satu jenis ternak ruminansia kecil yang cukup baik dalam mengkonversi pakan menjadi produk terutama daging. Produktivitas ternak dipengaruhi oleh genetik $40 \%$ dan lingkungan $60 \%$ berupa pakan, suhu dan kelembaban, intensitas cahaya, kesehatan, dan lain - lain. (Kurnianto, 2010). Rendahnya kualitas pakan juga mengakibatkan rendahnya produktivitas yang dihasilkan. Tingginya produktivitas kambing maka harus diimbangi dengan pakan yang berkualitas tinggi. Pakan yang diberikan harus memenuhi kebutuhan fisiologis dari ternak itu sendiri, misalnya yang harus diperhatikan adalah kandungan mineralnya.

Mineral yang dibutuhkan oleh tubuh ternak terbagi menjadi dua, yaitu mineral makro dan mineral mikro. Mineral makro ialah mineral yang dibutuhkan oleh metabolisme tubuh dalam jumlah besar contohnya ialah $\mathrm{Ca}, \mathrm{Mg}$ dan $\mathrm{P}$ sedangkan mineral mikro ialah mineral yang dibutuhkan oleh tubuh dalam jumlah sedikit contohnya adalah $\mathrm{Zn}$ dan $\mathrm{Cu}$ (Kurniawan, 2010). Peranan mineral penting dalam semua aspek metabolisme dalam tubuh dan apabila terjadi defisiensi atau kelebihan salah satu mineral akan mengganggu proses metabolisme yang berdampak dalam penurunan produksi atau reproduksi ternak. Mineral $\mathrm{Ca}, \mathrm{Mg}$ dan $\mathrm{P}$ adalah tiga unsur mineral makroessensial yang sangat dibutuhkan dalam proses metabolisme dan fisiologi tubuh ternak terutama pada waktu kebuntingan dimana Ca sangat diperlukan untuk pembentukan tulang pada janin (Darmono, 1995). Mineral $\mathrm{Zn}$ dan $\mathrm{Cu}$ adalah unsur mineral mikro yang sangat dibutuhkan oleh tubuh ternak untuk proses pembentukan hormon dan pertumbuhan bulu.

Rata - rata peternak tidak memperhatikan kecukupan mineral ternaknya sehingga mengalami defisiensi mineral. Ternak yang mengalami defisiensi mineral akan mengalami penurunan daya produksi dan reproduksi, sehingga solusi yang harus dilakukan yaitu memberi pakan tambahan sumber mineral agar kebutuhan nutrien ternak terpenuhi.

Multinutrien Blok atau (MNB) ialah suplemen yang diberikan untuk ternak yang bertujuan untuk meningkatkan proses amoniasi didalam rumen. Multinutrien blok terbuat dari campuran urea, molases, sumber serat dan sumber mineral yang tinggi. Tujuan utama dari suplemen multinutrien blok ialah mengkatalis atau mempercepat pemanfaatan pakan yang berkualitas rendah supaya lebih efisien diserap oleh tubuh ternak. Ternak ruminansia yang memiliki produktivitas tinggi seharusnya diberi pakan suplemen supaya menghemat pakan hijauan yang diberikan (Delima, 2008).

Penelitian ini bertujuan untuk mengevaluasi pengaruh pemberian pakan pelengkap Multinutrien Blok (MNB) dengan taraf pemberian yang berbeda $(0,5,10$ dan 15 gram) terhadap kadar mineral $(\mathrm{Ca}$, $\mathrm{Mg}, \mathrm{Cu}, \mathrm{Zn}$ dan $\mathrm{P}$ ) darah pada Kambing Kacang. Evaluasi digunakan untuk mengetahui ketersediaan mineral dalam darah.

\section{MATERI DAN METODE}

Penelitian dilaksanakan bulan MaretAgustus 2018 di Kandang percobaan Desa Mrunten Kel. Kalisidi, Kab. Semarang dan analisis laboratorium dilaksanakan di Laboratorium Ilmu Nutrisi Ternak Fakultas Peternakan dan Pertanian, Universitas Diponegoro, Semarang dan Laboratorium Kimia Organik Fakultas Kimia Universitas Negeri Semarang, Semarang.

\section{Materi}

Materi yang digunakan dalam penelitian ini antara lain obat cacing, multinutrien blok (MNB), Ransum, 12 buah spet $10 \mathrm{ml}$ dan jarum suntik, label, 12 buah tabung vacuulab dengan EDTA, cooling box, alkohol, alat tulis, 12 ekor kambing kacang jantan umur 7 bulan dengan 4 perlakuan level MNB yang berbeda. Kambing dibagi kedalam 3 kelompok bobot badan yaitu Kelompok I : 17,5 $20 \mathrm{~kg}$, Kelompok II : $15-16,5 \mathrm{~kg}$, Kelompok III : 13,5 - $15 \mathrm{~kg}$ setiap kelompok terdiri 4 ekor kambing. Setiap kelompok kambing mendapat 4 perlakuan berbeda berupa level pemberian MNB.

\section{Metode Penelitian \\ Pembuatan multinutrien blok (MNB)}

Proses pembuatan MNB diawali dengan hijauan jagung dicacah menggunakan chopper, cangkang kerang dan cangkang telur dicuci bersih dan dihancurkan secara manual dengan palu kemudian dijemur dibawah sinar matahari sampai kering, setelah kering di grinder untuk menyamakan ukuran partikel. Multinutrien Blok dibuat dengan perbandingan molasses $50 \%$, tepung hijauan jagung $30 \%$, urea $4 \%$, tepung cangkang kerang 3\%, tepung cangkang telur 3\%, garam 3\% dan bentonit 7\%. Pembuatan MNB dilakukan dengan metode panas yaitu dengan cara molasses dan urea dipanaskan pada suhu 40 - 500C selama 10 menit. Tepung cangkang kerang, tepung cangkang telur, garam dan bentonit dicampur secara terpisah karena jumlahnya sedikit. Campurkan seluruh bahan dengan urutan dari 
bahan yang jumlahnya paling banyak ke bahan yang jumlahnya paling sedikit sampai homogen. Setelah itu dicetak dengan pipa paralon, kemudian MNB diangin - anginkan beberapa hari sampai sedikit mengeras. MNB yang sudah jadi dimasukkan kedalam plastik dan disimpan.

\section{Pelaksanaan penelitian menggunakan ternak kambing}

Kambing kacang umur 7 bulan dipelihara dalam kandang individu dan diadaptasikan selama 2 bulan. Awal kambing masuk diberikan obat cacing. Selama masa adaptasi kambing diberikan ransum yang tersusun atas hijauan jagung yang diberikan secara ad-libitum dan pelatihan terhadap pakan konsentrat secara sedikit demi sedikit. Setelah 2 bulan kambing ditimbang dan dikelompokkan berdasarkan bobot badan ke dalam 3 kelompok yaitu Kelompok I : 17,5 - $20 \mathrm{~kg}$, Kelompok II : 15 - 16,5 kg, Kelompok III : 13,5 - 15 kg setiap kelompok terdiri 4 ekor kambing. Kambing diberi pakan 2 kali sehari yang tersusun atas hijauan dan konsentrat, selain itu juga disediakan air minum secara ad-libitum. Kambing diberi ransum perlakuan selama 2 bulan yang disusun sesuai bobot badan ternak saat memasuki prelim. Ransum diberikan secara terukur (restricted) sesuai kebutuhan ternak menurut bobot badan.

Tahap perlakuan kambing diberikan ransum perlakuan setiap kelompok dengan level MNB yang berbeda tiap kambing selama 1 bulan. Perlakuan I berupa ransum tanpa MNB, perlakuan II ransum dengan penambahan MNB 5 gram, perlakuan III ransum dengan penambahan MNB 10 gram, dan perlakuan IV ransum dengan penambahan MNB 15 gram. Pemberian MNB dilakukan sebelum kambing diberi pakan. Pengambilan darah kambing dilakukan setelah kambing diberi pakan, kurang lebih 4 jam setelah pemberian hijauan. Sampel darah diambil sebayak 7 - $9 \mathrm{ml}$ tiap ekornya menggunakan spet dan jarum suntik. Sampel darah yang sudah diambil dimasukkan ke dalam tabung vacuulab dan diberi label, kemudian dimasukkan ke dalam cooling box.

\section{Analisis Data}

Rancangan penelitian yang akan digunakan yaitu rancangan acak kelompok (RAK) dengan 4 perlakuan dan 3 ulangan. Perlakuan yang diberikan yaitu :

T0 : Hijauan + Konsentrat + Tanpa Pemberian MNB.

T1 : Hijauan + Konsentrat + MNB sebanyak 5

g.

T2 : Hijauan + Konsentrat + MNB sebanyak $10 \mathrm{~g}$.

T3 : Hijauan + Konsentrat + MNB sebanyak $15 \mathrm{~g}$.

Semua data yang diperoleh kemudian diolah dan dianalisa menggunakan uji ANOVA, jika diperoleh hasil yang signifikan maka dilakukan Uji Jarak Berganda Duncan.

\section{HASIL DAN PEMBAHASAN}

\section{Kalsium (Ca)}

Hasil analisis kadar mineral $\mathrm{Ca}$ darah kambing yang diberi perlakuan berbagai level MNB mulai dari 0,5 . 10, dan 15 gram dapat dilihat pada Tabel 1.

Hasil uji analisis kadar mineral Ca plasma darah kambing kacang diketahui pada perlakuan kontrol (ransum tanpa MNB) kadar mineral $\mathrm{Ca}$ sejumlah $116,07 \mathrm{mg} / \mathrm{l}$, perlakuan I (ransum +5 gram MNB) sebesar 116,07 mg/l, perlakuan II (ransum + 10 gram MNB) sebesar $116,23 \mathrm{mg} / \mathrm{l}$, dan perlakuan III (ransum + 15 gram MNB) sebesar 116,20 mg/l. Kadar mineral $\mathrm{Ca}$ plasma darah kambing tertinggi terdapat pada perlakuan II berupa ransum dengan pemberian MNB 10 gram.

Tabel 1. Kadar Mineral Ca Plasma Darah Kambing Kacang

\begin{tabular}{lrrrrr}
\hline \multirow{2}{*}{\multicolumn{1}{c}{ Perlakuan }} & \multicolumn{3}{c}{ Kelompok } & \multirow{2}{*}{ Jumlah } & \multirow{2}{*}{ Rata - rata } \\
\cline { 2 - 4 } & I & II & III & & \\
\cline { 2 - 4 } Ransum tanpa MNB & 116,2 & 116,1 & 115,9 & 348,2 & 116,07 \\
Ransum + 5 gram MNB & 115,9 & 116,0 & 116,3 & 348,2 & 116,07 \\
Ransum + 10 gram MNB & 116,0 & 116,1 & 116,6 & 348,7 & 116,23 \\
Ransum + 15 gram MNB & 116,0 & 116,4 & 116,2 & 348,6 & 116,20 \\
\hline
\end{tabular}

Tabel 1 menunjukkan bahwa pengaruh pemberian MNB tidak berpengaruh terhadap peningkatan kadar mineral Ca dalam plasma darah.
Kadar mineral Ca tertinggi terdapat pada pemberian MNB (perlakuan II) sebesar 116,23 mg/l. Menurut pendapat Coles. (1974) menyatakan bahwa kadar 
Ca didalam plasma darah kambing normal berkisar antara $107-120 \mathrm{mg} / \mathrm{l}$. Hal ini menunjukkan bahwa pemberian level MNB tidak terjadi peningkatan yang signifikan namun masih dalam taraf kadar normal. Hal ini disebabkan karena jika tubuh ternak sudah menyerap mineral Ca sesuai kebutuhan tubuh maka tidak akan menyerap lagi sehingga kelebihan mineral $\mathrm{Ca}$ akan dibuang melalui feses dan urin. Hal ini sesuai dengan pendapat Payne, (1977) yang menyatakan bahwa penyerapan kalsium pada tubuh sesuai dengan kebutuhannya dan tidak berlebih, sehingga apabila kebutuhan kalsium di dalam tubuh berkurang maka penyerapannya akan meningkat.

Apabila penyerapan $\mathrm{Ca}$ didalam tubuh mengalami kekurangan maka dapat berdampak buruk bagi keseimbangan metabolisme tulang dan dapat mengakibatkan kematian jika terjadi pada jangka panjang. Piliang, (2002) menyatakan bahwa jika ransum ternak mengalami defisiensi Ca maka pembentukan tulang menjadi kurang sempurna dan akan mengakibatkan penyakit tulang. Blood dan Henderson, (1974) menyatakan bahwa kematian ternak dapat terjadi bila terdapat pengaruh sekunder yang disertai penipisan tulang yang diakibatkan kekurangan kalsium pada pakan. Penyerapan $\mathrm{Ca}$ didalam tubuh dapat dipengaruhi oleh beberapa faktor antara lain dari segi kualitas formulasi pakan dan fisiologi tubuh. Menurut Crampton dan Lloyd, (1959) menyatakan bahwa jumlah kalsium yang diserap didalam tubuh dipengaruhi beberapa faktor yaitu pakan, $\mathrm{pH}$ cairan rumen, bandingan kalsium dan fosfor dan vitamin D dalam pakan. Piliang, (2002) menyatakan bahwa beberapa faktor pakan dapat membantu meningkatkan penyerapan $\mathrm{Ca}$, sedangkan ada beberapa faktor lain dapat menurunkan penyerapan $\mathrm{Ca}$ oleh usus halus yaitu asam fitat dan asam oksalat. Asam fitat dan asam oksalat dapat mengikat $\mathrm{Ca}$ dan membentuk garam Ca yang tidak larut dalam lumen usus halus.

\section{Fosfor (P)}

Hasil analisis kadar mineral $\mathrm{P}$ darah kambing yang diberi perlakuan berbagai level MNB mulai dari $0,5,10$, dan 15 gram dapat dilihat pada Tabel 2.

Hasil uji analisis kadar mineral $\mathrm{P}$ plasma darah kambing kacang diketahui pada perlakuan kontrol (ransum tanpa MNB) kadar mineral $\mathrm{P}$ sejumlah 94,847 mg/l, perlakuan I (ransum +5 gram MNB) sebesar $91,817 \mathrm{mg} / \mathrm{l}$, perlakuan II (ransum + 10 gram MNB) sebesar 94,243 mg/l, dan perlakuan III (ransum +15 gram MNB) sebesar $94,847 \mathrm{mg} / \mathrm{l}$.

Tabel 2. Kadar Mineral P Plasma Darah Kambing Kacang

\begin{tabular}{lrcccc}
\hline \multirow{2}{*}{\multicolumn{1}{c}{ Perlakuan }} & \multicolumn{3}{c}{ Kelompok } & \multirow{2}{*}{ Jumlah } & \multirow{2}{*}{ Rata - rata } \\
\cline { 2 - 4 } & \multicolumn{1}{c}{ I } & II & III & & \\
\cline { 2 - 3 } Ransumtanpa MNB & 95,45 & 90,91 & 98,18 & 284,54 & 94,847 \\
Ransum + 5 gram MNB & 90,91 & 89,09 & 95,45 & 275,45 & 91,817 \\
Ransum + 10 gram MNB & 93,64 & 93,64 & 95,45 & 282,73 & 94,243 \\
Ransum + 15 gram MNB & 96,36 & 89,09 & 99,09 & 284,54 & 94,847 \\
\hline
\end{tabular}

Tabel 2 menunjukkan bahwa pengaruh pemberian multinutrien blok (MNB) tidak berpengaruh terhadap peningkatan kadar mineral $\mathrm{P}$ dalam plasma darah. Kadar mineral $\mathrm{P}$ tertinggi terdapat pada perlakuan III pemberian MNB 15 gram yaitu sebesar $94,847 \mathrm{mg} / \mathrm{l}$ yang memiliki nilai lebih tinggi dari taraf normal kadar P didalam tubuh. Menurut Coles, (1974) Kandungan P secara normal dalam plasma darah berkisar 52,1 mg/l. Tingginya kadar mineral $\mathrm{P}$ di dalam plasma darah disebabkan oleh penyerapan mineral $\mathrm{P}$ didalam usus halus yang dipengaruhi oleh perbandingan kandungan mineral $\mathrm{Ca}$ dan $\mathrm{P}$ didalam pakan yang dicerna dan $\mathrm{pH}$ didalam usus halus. Hal ini sesuai dengan pendapat Crampton dan Lloyd, (1959) menyatakan bahwa absorpsi fosfor terjadi pada usus halus bagian bawah dan jumlah fosfor yang diserap sulit diketahui karena dipengaruhi oleh beberapa faktor yaitu pakan, $\mathrm{pH}$ cairan usus, bandingan kalsium dan fosfor dalam pakan dan vitamin D. Payne, (1977) menyatakan bahwa perbandingan yang optimal antara mineral kalsium dan fosfor untuk pakan ternak ruminansia adalah 2:1.

Kadar konsentrasi mineral P didalam tubuh terlalu tinggi maka akan dapat menggangu fungsi mineral yang lainnya didalam tubuh. Menurut Crampton dan Lloyd, (1959) menyatakan bahwa kandungan fosfor yang berlebihan atau terlalu tinggi didalam tubuh dapat menyebabkan penurunan fungsi kalsium didalam tubuh. Mineral fosfor memiliki fungsi sebagai pembentuk tulang, gigi dan membantu perkembangan mikroba tumen. Hal ini sesuai dengan pendapat Williamson dan Payne, (1993) menyatakan bahwa fosfor sama juga kalsium memiliki fungsi sebagai pembentuk tulang dan gigi, dan berperan dalam fosforilasi dan oksidasi beberapa enzim penting didalam tubuh. Fosfor juga merupakan kofaktor enzim, asam nukleat dan lipida - lipida fosfor, dan mempunyai peranan dalam metabolisme kalsium. Vrzgula, (1990) menyatakan 
bahwa pada ternak ruminansia fosfor dibutuhkan untuk perangsang kelenjar saliva didalam mulut dan perkembangan mikroba didalam rumen.
Hasil analisis kadar mineral $\mathrm{Mg}$ darah kambing yang diberi perlakuan berbagai level MNB mulai dari $0,5,10$, dan 15 gram dapat dilihat pada Tabel 3.

\section{Magnesium (Mg)}

Tabel 3. Kadar Mineral Mg Plasma Darah Kambing Kacang

\begin{tabular}{|c|c|c|c|c|c|}
\hline \multirow{3}{*}{ Perlakuan } & \multicolumn{3}{|c|}{ Kelompok } & \multirow{2}{*}{ Jumlah } & \multirow{2}{*}{ Rata - rata } \\
\hline & I & II & III & & \\
\hline & \multicolumn{5}{|c|}{ 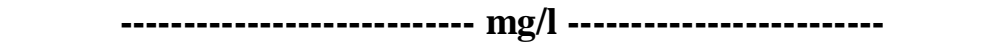 } \\
\hline Ransum tanpa MNB & 5,233 & 9,474 & 11,450 & 26,157 & 8,719 \\
\hline Ransum + 5 gram MNB & 7,605 & 9,211 & 13,030 & 29,846 & 9,949 \\
\hline Ransum +10 gram MNB & 9,660 & 8,541 & 7,255 & 25,456 & 8,485 \\
\hline Ransum + 15 gram MNB & 7,118 & 9,430 & 10,480 & 27,028 & 9,009 \\
\hline
\end{tabular}

Hasil uji analisis kadar mineral Mg plasma darah kambing kacang diketahui pada perlakuan kontrol (ransum tanpa MNB) kadar mineral $\mathrm{Mg}$ sejumlah $8,719 \mathrm{mg} / \mathrm{l}$, perlakuan I (ransum +5 gram MNB) sebesar 9,949 mg/l, perlakuan II (ransum + 10 gram MNB) sebesar $8,485 \mathrm{mg} / \mathrm{l}$, dan perlakuan III (ransum + 15 gram MNB) sebesar 9,009 mg/l. Kadar mineral Mg plasma darah kambing tertinggi terdapat pada perlakuan I berupa ransum dengan pemberian MNB 5 gram.

Tabel 3 menunjukkan bahwa pengaruh pemberian multinutrien blok (MNB) tidak berpengaruh terhadap peningkatan kadar mineral $\mathrm{Mg}$ dalam plasma darah. Kadar mineral $\mathrm{Mg}$ tertinggi terdapat pada perlakuan I pemberian MNB 5 gram yaitu sebesar $9,949 \mathrm{mg} / \mathrm{l}$ yang kurang dalam taraf normal kadar $\mathrm{Mg}$ didalam tubuh. Menurut Georgievskii, (1982) kadar normal magnesium di dalam plasma darah kambing yang dikatakan sehat berkisar antara $18-24 \mathrm{mg} / \mathrm{l}$. Rendahnya kadar mineral Mg di dalam plasma darah disebabkan oleh penyerapan mineral $\mathrm{Mg}$ didalam usus halus yang tidak maksimal. Hal ini sesuai dengan pendapat Ensminger et al., (1990) bahwa sekitar 30-50\% Mg dari rata - rata konsumsi harian ternak akan diserap di usus halus, penyerapan ini dipengaruhi oleh beberapa faktor yaitu oleh protein, laktosa, vitamin $\mathrm{D}$, hormon pertumbuhan dan antibiotik.

Berkurangnya kadar mineral $\mathrm{Mg}$ didalam tubuh secara terus menerus maka dapat mengakibatkan penurunan nafsu makan, gangguan reproduksi dan turunnya produksi. Toharmat dan Sutardi, (1985) menyatakan bahwa perubahan konsentrasi Mg dari keadaan normal selama 2-18 hari dapat menyebabkan hipomagnesemia. Robinson et al., (1989) menambahkan bahwa defisiensi $\mathrm{Mg}$ mengakibatkan penurunan nafsu makan sehingga menurunkan asupan nutrisi keseluruhan, turunnya asupan pakan secara total dapat mempengaruhi produksi ternak. Magnesium memiliki fungsi sebagai kofaktor dari beberapa enzim yang membantu proses pencernaan. Menurut Ebel dan Gunther, (1980) bahwa fungsi Mg scara umum sebagai kofaktor lebih dari 300 enzim yang berperan dalam metabolisme karbohidrat, lemak dan protein.

\section{Seng (Zn)}

Hasil analisis kadar mineral $\mathrm{Zn}$ darah kambing yang diberi perlakuan berbagai level MNB mulai dari $0,5,10$, dan 15 gram dapat dilihat pada Tabel 4.

Tabel 4. Kadar Mineral Zn Plasma Darah Kambing Kacang

\begin{tabular}{lrcccc}
\hline \multirow{2}{*}{\multicolumn{1}{c}{ Perlakuan }} & \multicolumn{3}{c}{ Kelompok } & \multirow{2}{*}{ Jumlah } & \multirow{2}{*}{ Rata- rata } \\
\cline { 2 - 6 } & & II & III & & \\
\cline { 2 - 6 } Ransumtanpa MNB & 95,45 & 90,91 & 98,18 & 284,54 & 94,847 \\
Ransum + 5 gram MNB & 90,91 & 89,09 & 95,45 & 275,45 & 91,817 \\
Ransum + 10 gram MNB & 93,64 & 93,64 & 95,45 & 282,73 & 94,243 \\
Ransum + 15 gram MNB & 96,36 & 89,09 & 99,09 & 284,54 & 94,847 \\
\hline
\end{tabular}

Hasil penghitungan kadar mineral $\mathrm{Zn}$ plasma darah kambing kacang diketahui pada perlakuan kontrol (ransum tanpa MNB) kadar mineral $\mathrm{Zn}$ sejumlah $0,1843 \mathrm{mg} / \mathrm{l}$, perlakuan I (ransum + 5 gram MNB) sebesar $0,1183 \mathrm{mg} / \mathrm{l}$, perlakuan II (ransum +10 gram MNB) sebesar 
0,1217 mg/l, dan perlakuan III (ransum + 15 gram MNB) sebesar $0,1253 \mathrm{mg} / \mathrm{l}$. Kadar mineral $\mathrm{Zn}$ plasma darah kambing tertinggi terdapat pada perlakuan kontrol berupa ransum tanpa penambahan MNB sebesar 0,1843 mg/l.

Tabel 4 diketahui bahwa pengaruh pemberian Multinutrien Blok (MNB) tidak berpengaruh terhadap peningkatan kadar mineral $\mathrm{Zn}$ dalam plasma darah. Kadar perubahan mineral Zn dalam darah tertinggi terdapat pada perlakuan kontrol, yang menghasilkan kadar sebesar 0,1843 $\mathrm{mg} / \mathrm{l}$. Hasil ini kurang dari normal dibandingkan dengan pendapat Georgievskii et al., (1982) menyatakan bahwa rata - rata konsentrasi $\mathrm{Zn}$ dalam plasma darah ternak antara $1-2 \mathrm{mg} / \mathrm{l}$. Rendahnya kadar mineral $\mathrm{Zn}$ di dalam plasma darah disebabkan oleh rendahnya kandungan $\mathrm{Zn}$ didalam pakan serta penyerapan mineral $\mathrm{Zn}$ di pakan kurang maksimal diserap oleh rumen dan usus halus. Hal ini sesuai dengan pendapat Underwood, (1999) menyatakan bahwa absorpsi seng dapat dipengaruhi oleh jumlah dan imbangan mineral lain pada pakan serta kandungan seng didalam ransum dan bentuk seng yang diserap oleh tubuh. Georgievskii et al., (1982) menambahkan bahwa tingginya level penyerapan kalsium didalam pakan juga dapat menghambat penyerapan seng didalam usus halus.
Rendahnya kadar Zn didalam tubuh juga dapat mempengaruhi aktivitas berbagai enzim dan dapat menimbulkan penurunan nafsu makan sampai gangguan sistem immunitas tubuh. Menurut NAS, (1980) bahwa defisiensi Zn mengakibatkan penurunan aktivitas berbagai enzim dan keadaan tersebut dapat menimbulkan berbagai gejala klinis yang tampak adalah alopesia, dermatitis, parakeratosis dan bulu, kaki dan kulit yang tidak normal. Underwood, (1999) menambahkan bahwa kekurangan seng akan terjadi penurunan nafsu makan sampai gangguan sistem pertahanan tubuh atau immunitas. Fungsi mineral $\mathrm{Zn}$ yaitu sebagai kofaktor berbagai enzim. Linder, (1992) menyatakan bahwa $\mathrm{Zn}$ diperlukan untuk aktivitas lebih dari 90 enzim yang ada hubungannya dengan metabolisme karbohidrat dan energi, degradasi atau sintesis protein, sintesis asam nukleat, biosintesis heme, transfer $\mathrm{CO} 2$ dan reaksi - reaksi lain.

\section{Tembaga $(\mathrm{Cu})$}

Hasil analisis kadar mineral $\mathrm{Cu}$ darah kambing yang diberi perlakuan berbagai level MNB mulai dari $0,5,10$, dan 15 gram dapat dilihat pada Tabel 5 .

Tabel 5. Kadar Mineral Cu Plasma Darah Kambing Kacang

\begin{tabular}{|c|c|c|c|c|c|}
\hline \multirow{3}{*}{ Perlakuan } & \multicolumn{3}{|c|}{ Kelompok } & \multirow{2}{*}{ Jumlah } & \multirow{2}{*}{ Rata - rata } \\
\hline & $\mathbf{I}$ & II & III & & \\
\hline & \multicolumn{5}{|c|}{ 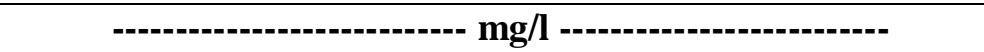 } \\
\hline Ransum tanpa MNB & 0,203 & 0,166 & 0,192 & 0,561 & 0,187 \\
\hline Ransum + 5 gram MNB & 0,162 & 0,163 & 0,167 & 0,492 & 0,164 \\
\hline Ransum +10 gram MNB & 0,162 & 0,169 & 0,176 & 0,507 & 0,169 \\
\hline Ransum + 15 gram MNB & 0,156 & 0,175 & 0,164 & 0,495 & 0,165 \\
\hline
\end{tabular}

Hasil penghitungan kadar mineral $\mathrm{Cu}$ plasma darah kambing kacang diketahui pada perlakuan kontrol (ransum tanpa MNB) kadar mineral $\mathrm{Cu}$ sejumlah $0,187 \mathrm{mg} / \mathrm{l}$, perlakuan I (ransum + 5 gram MNB) sebesar 0,164 mg/l, perlakuan II (ransum +10 gram MNB) sebesar $0,169 \mathrm{mg} / \mathrm{l}$, dan perlakuan III (ransum +15 gram MNB) sebesar 0,165 mg/l. Kadar mineral Zn plasma darah kambing tertinggi terdapat pada perlakuan kontrol berupa ransum tanpa penambahan MNB sebesar 0,187 mg/l.

Tabel 5 diketahui bahwa pengaruh pemberian Multinutrien Blok (MNB) tidak berpengaruh terhadap peningkatan kadar mineral $\mathrm{Cu}$ dalam plasma darah. Kadar perubahan mineral $\mathrm{Cu}$ dalam darah tertinggi terdapat pada perlakuan kontrol, yang menghasilkan kadar sebesar 0,187 $\mathrm{mg} / \mathrm{l}$. Hasil ini kurang dari normal dibandingkan dengan pendapat Blood dan Henderson, (1974) menyatakan bahwa kandungan tembaga secara normal dalam plasma darah berkisar antara $0,6-1,5$ $\mathrm{mg} / \mathrm{l}$. Rendahnya kadar mineral $\mathrm{Cu}$ di dalam plasma darah disebabkan oleh tingginya kadar mineral Zn, $\mathrm{Ca}$ dan $\mathrm{Fe}$ yang dapat mengurangi penyerapan $\mathrm{Cu}$ didalam usus halus. Hal ini sesuai dengan pendapat Chowdhury dan Chandra, (1987) menyatakan bahwa faktor - faktor yang mempengaruhi daya serap tembaga dalam tubuh yaitu kadar seng, zat kapur dan besi yang memiliki kadar tinggi dapat mengurangi penyerapan tembaga oleh intestinum.

Rendahnya kadar $\mathrm{Cu}$ didalam tubuh juga dapat mempengaruhi aktivitas berbagai enzim dan dapat menimbulkan penyakit anemia dan gangguan gastrointestinal. Darmono dan Bahri, (1989) menyatakan bahwa apabila kekurangan tembaga dalam darah dapat menyebabkan anemia yang merupakan gejala umum, akan terjadi pertumbuhan yang terganggu, kerusakan tulang, depigmentasi bulu, pertumbuhan abnormal dari bulu dan gangguan gastrointestinal. Sharma et al., (2003) 
menambahkan bahwa selain ikut serta salam sintesa hemoglobin, tembaga juga merupakan bagian dari enzim - enzim didalam sel, seperti sebagai kofaktor enzim tirosinase didalam kulit.

\section{KESIMPULAN}

Berdasarkan hasil penelitian diketahui bahwa pemberian MNB dengan taraf $(0,5,10,15 \mathrm{~g})$ memberikan efek yang sama terhadap status mineral $(\mathrm{Ca}, \mathrm{P}, \mathrm{Mg}, \mathrm{Zn}, \mathrm{Cu}$ ) dalam plasma darah kambing kacang.

\section{REFERENSI}

Blood, D. C. dan J. A. Henderson. 1974. Veterinary Medicine. Baillere Tindall, London.

Chowdhury, B. A. dan R. K. Chandra. 1987. Biological and health implication of toxic heavy metals and essential trace element intractions. Progress in Food and Nutrition Science. 28 (1): 55-113.

Crampton, E. W., dan L. E. Lloyd. 1959. Fundamental of Nutrition. W. H. Freeman and Company, Sanfrancisco.

Coles, E. H. 1974. Veterinary Clinical Pathology. W. B. Saunder Co., Philadelphia.

Darmono dan S. Bahri. 1989. Status beberapa mineral makro ( $\mathrm{Na}, \mathrm{K}, \mathrm{Ca}, \mathrm{Mg}$, dan $\mathrm{P}$ ) dalam saliva dan serum sapi di Kalimantan Selatan. Penyakit Hewan. 22 (40): 138-142.

Darmono. 1995. Logam dalam Sistem Biologi Makhluk Hidup. Penerbit Universitas Indonesia (UI Press), Jakarta.

Delima, M. 2008. Pengaruh pemberian urea molases mineral blok terhadap kadar mineral serum sapi yang memperlihatkan gejala defisiensi mineral. Agripet. 8 (1): 45-49.

Ebel, H. and Gunther, T. (1980). Magnesium metabolism. Journal of Clinical Chemistry and Clinical Biochemistry. 18 (1): 257-270.

Ensminger, M. E., J. E. Oldfield dan W. W. Heinemann. 1990. Feeds and Nutritiom Digest. Institut des Sciences Agronomiques du Burundi, Bujumbura.
Georgievskii. 1982. Mineral Nutrition of Animal. English Transition Butterworth and Co., English.

Kurnianto, E. 2010. PemuliaanTernak. Graha Ilmu, Yogyakarta.

Kurniawan. 2010. Status Kandungan Mineral Pada Sapi yang Bunting dan Tidak Bunting Setelah di IB di Kecamatan Ketaping Kabupaten Padang Pariaman. Fakultas Peternakan, Universitas Andalas, Padang. Tesis.

Linder, C. M. 1992. Nutritional Biochemistry and Metabolism. California State University, California.

National Academy of Sciences (NAS). 1980. Mineral Tolerance of Domestic Animals. Washington, D.C.

Payne, J. M. 1977. Metabolic Diseases in Farm Animal. William Heinemann Medical Books Ltd, London.

Piliang, W. G. 2002. Nutrisi Vitamin. Institut Pertanian Bogor, Bogor.

Robinson, D. L., L. C. Kappel dan J. A. Boling. 1989. Management Practices to Overcome the Incidence of Grass Tetany. Journal of Animal Science. 67 (12): 3470-3484.

Sharma, M. C., S. Raju, C. Joshi, H. Kaur dan V. P. Varshney. 2003. Studies on serum micromineral, hormone and vitamin profile and its effect on production and therapeutic management of buffaloes in Haryana State of India. J. Animal Science. 16 (4): 519-528.

Toharmat, T dan T. Sutardi. 1985. Kebutuhan mineral makro untuk produksi Susu pada sapi perah laktasi Dihubungkan dengan kondisi faalnya. Karya Ilmiah. Fakultas Peternakan Institut Pertanian Bogor, Bogor.

Underwood, E. J. dan N. F. Suttle. 1999. The Mineral Nutrition of Livestock. CAB International, Wallingford.

Vrzgula, L. 1990. Metabolic Disorders and their Prevention in Farm Animals. Amsterdam Elsevier, Amsterdam.

Williamson dan G. Payne. 1993. Pengantar Peternakan di Daerah Tropis. Universitas Gajah Mada Press, Yogyakarta. (Diterjemahkan oleh S.G.N.D. Darmadja). 